\title{
Characterization of the Operation of the Diet in Patient Diabetic Geriatrics
}

\author{
Jesús Cuéllar Alvarez ${ }^{1 *}$, Elizabeth Leal Ruíz ${ }^{2}$ and Leonardo Rodríguez Méndez ${ }^{3}$ \\ ${ }^{1}$ MSc in Psycho pedagogic, Clinical health psychologist, Policlinic José Ramón León Acosta, Cuba \\ ${ }^{2}$ Dr in Medicine, Endocrinologist, Policlinic, José Ramón León Acosta, Cuba \\ ${ }^{3} \mathrm{Dr} C$ Titular professor, Central University "Marta Abreu" of the Villas, Cuba
}

*Corresponding author: Jesús Cuéllar Alvarez, MSc in Psycho pedagogic, Clinical health psychologist, Policlinic "José Ramón

León Acosta", Cuba

\section{ARTICLE INFO}

Received: 慧 May 25, 2019

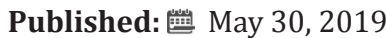

Citation: AJesús Cuéllar A, Elizabeth Leal R, Leonardo Rodríguez M. Characterization of the Operation of the Diet in Patient Diabetic Geriatrics. Biomed J Sci \& Tech Res 18(3)-2019. BJSTR. MS.ID.003161.

Keywords: Aging; Diabetic; Health; Bigger Adults

\section{ABSTRACT}

Background: The diabetic in bigger adults is necessary to prevent illness from the sciences of the health.

Objective: To characterize of the operation of the diet in patient diabetic geriatrics.

Methods: Was carried out a study decriptivo, restrospective, with a sample composed by 30 old patients as universe with a sample of 18 belonging of the Policlinic "José Ramón León Acosta. It gathers it of the data was carried out through the empiric method as the questionnaire and for the analysis of the data the statistical calculation was used.

Results: The state of individual health of this group prevailed as for knowledge that will allow them to modify its lifestyle and in turn an aging very happened to the minimum of limitations.

Conclusion: The difficulties are focused in the systematic of the development psicosocial and to prevent factors normative for the sanitary and social structure in bigger adults.

\section{Introduction}

The older adult in Cuba occupies more than 19\%, and it is expected that by 2025, one in four Cubans will be older adults. Of this population only one percent is in institutions, $9 \%$ live alone and the rest live with family members [1]. The so-called third age, also known in the terms of old age, late or adulthood, has been addressed in the literature in isolation or as a phase of involution and not as an authentic stage of human development. It is located around the age of sixty, associated with the event of occupational retirement [2]. The call third age, bigger or later adulthood, it has been approached in the medical literature in an isolated way and I don't eat an authentic stage of the human development [3]. Physical rehabilitation consists of restoring the affected function by means of specific interventions, which obey a plan previously established on the basis of the clinical characteristics of the patient in question.
Its ultimate goal is the recovery of functions, so that the patient can meet daily demands with a minimum of efficiency [4-6]. In spite of the demographic increase and the high degree of population aging that Cuba exhibits, there are not ample references of research in relation to the geriatric study that measure the cognitive and affective state, however, there are statistical data that have been attended and offered monitoring and special treatment of the psychological well-being of the elderly, precisely in these last five years [7-10]. The objective of the present investigation was to characterize of the operation of the diet in patient diabetic geriatrics.

\section{Methods}

A study descriptive- retrospective, approach was carried out in elderly patients attended from a community health area belonging to the "José Ramón León Acosta” polyclinic of Santa Clara 
municipality, in the period from September 2018 to April 2019 The sample was selected through the simple random sampling probabilistic technique and consisted of 18 old patients, previously informed consent to participate in the study.

\section{Theoretical Level}

a) Synthetic Analytical: It made possible the interpretation of each one of the studied texts, to conform the criterion assumed in the epigraphs and paragraphs, as well as to particularize in the data obtained in the surveys to integrate them and to establish the corresponding generalizations.

b) Inductive-Deductive: It facilitated going from the particular to the general in each of the analyzes carried out in the theoretical study and in the processing of the obtained information.

c) Generalization: It allowed the establishment of the regularities that were revealed in the study carried out.

\section{Empiric Level}

a) Open interview: Contributed to identify the self-regulation indicators in the patient diabetic geriatrics.

b) Individual clinical histories: It made it possible to provide information on various personal aspects.

The selection was based on the following approaches:

\section{Inclusion Approaches}

a. All the patients of both sexes, older adults between 60 to 80 years of age. b. Elderly patients who give their consent to participate in the investigation.

\section{Exclusion Approaches}

Patients with a psychiatric history whose psychotic level prevents them from cooperating with the study were excluded.

\section{Exits Approaches}

Patients that abandon the investigation voluntarily.

\section{Collection of the Information}

For the collection of information, a form was designed with the variables that were to be investigated, which included general data, such as age, sex and patient diabetic geriatrics. In addition, the open interview was conducted, with prior informed consent.

\section{Statistical Analysis}

Once the information was collected, an automated database was created, supported on Windows Microsoft Excel, from which the frequency distributions for the tables and graphs that summarized the primary data were extracted. Descriptive statistics techniques were applied to obtain absolute frequencies and percentages.

\section{Results}

Before the intervention, the basic knowledge on dietary régime are not high $(55,5 \%)$, after the application there was a change for well in the knowledge, until of a $(83,3 \%)$, what is translated in possible changes of lifestyles as for feeding. The intervention improves the knowledge it has more than enough nutrition after the intervention with a dependability of more than 95\% (Table 1).

Table 1: Level of knowledge on the diet in patient diabetis geriatrics.

\begin{tabular}{|c|c|c|c|c|}
\hline \multirow{2}{*}{ Level of knowledge on the diet } & \multicolumn{2}{|c|}{ Before } & \multicolumn{2}{|c|}{ After } \\
\hline & $\#$ & $\%$ & \# & $\%$ \\
\hline High & 3 & 16 & 15 & 83,3 \\
\hline Half & 5 & 27,7 & 3 & 16,3 \\
\hline Under & 10 & 55,5 & 18 & 100 \\
\hline
\end{tabular}

Source: Clinical history of health.

\section{Discussion}

The aging process brings I get the reduction of the physical capacity and the development of an individual's deterioration cognitive [11-13]. Nevertheless, diverse pathologies, accidents, history of life, loads genetics and aspects psychologic and social can influence in the speed and severity of such conditions, even in the condition of functional dependence [14]. In connection with the grade of independence, this study coincides with the author Marinês Tambara and other [15] where almost $85 \%$ of the old men was independent, continued by those with partial dependence (9\%). Several works have demonstrated that the depressive symptoms are related with a precarious health and a functional inability, for what is considered as a problem of very important public health and their study is integral part of the investigations about the well-being and the health of people of advanced age [1618]. In the literature on the sciences of the health has been picked up that relationship exists between the escolaridad level and the state cognitive of the biggest adults. The old men with low escolaridad grade are hindered the understanding and realization of tasks.

The interest for the adjusted lifestyle to the physical sphere, cognitive and affective in the biggest adults they make that by means of pursuit and attendance with the help of the diverse professionals implied with the direct work in rehabilitation achieve an appropriate active or successful aging as primary process that implies gradual and unavoidable changes related with the age, which appear in all the members of a species $[17,18]$. The aging process is 
normal and it happens in spite of the fact that the individual of enjoyment of good health or maintain a healthy lifestyle and I activate. Therefore, it is indispensable for the attention and health integral geriátrica to take conscience singular of their own state of health psychologic and social, spiritual and cultural [15]. By way of conclusion, the age is the unavoidable result of the organic and mental deterioration, which becomes visible by the middle of the life and it progresses to a quick rhythm. To age like biological process has extensive social and psychological consequences in today's world and especially in the county of Villa Clara, where the population's aging increases, what implies that the biggest adults demand actions integrated with the help of professionals and the intervention of different sectors that cover their diverse biological, psychological and social necessities [15].

\section{Conclusion}

The magnitude of the population's aging doesn't have precedents; it is a process without limits in the humanity's history, the number of grown-ups increases exponentially in complex and uncertain socioeconomic joints. The development of professional competitions that offer attention to the biggest adult to guarantee the quality and the excellence in the attention of health, will allow Potencia an appropriate lifestyle and to prevent that becomes a crisis factor for the sanitary structure. The obtained results are notably positive on the cost of their implementation in the current socioeconomic assisting to the focus psychologic and social in health, about the improvement of the lifestyle of this group , as for knowledge that will allow them to modify their state of health and in turn an aging very happened to the minimum of discapacity and this way the development psychologic and social and to prevent that the aging becomes a factor of normative for the sanitary structure and of the social security.

\section{References}

1. Álvarez R (2013) Evolución del envejecimiento en la población cubana. Temas de MGI. La Habana: Editorial Ciencias Médicas (1).

2. Orosa $T$ (2012) La tercera edad y la familia [Internet]. La Habana: Editorial Félix Varela.

3. Luria AR (1973) Fundamentos de Neuropsicología [Internet]. Barcelona: Fontanella.

\section{ISSN: 2574-1241}

DOI: 10.26717/BJSTR.2019.18.003161

Jesús Cuéllar Alvarez. Biomed J Sci \& Tech Res

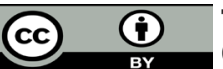

This work is licensed under Creative

Commons Attribution 4.0 License

Submission Link: https://biomedres.us/submit-manuscript.php
4. Vigotsky LS (1985) Historia del desarrollo de las funciones psíquicas superiores [Internet]. La Habana: Editorial Científico Técnica.

5. Cuetos F Neuropsicología cognitiva del lenguaje (2013) In: De Vega M, Cuetos F(eds.), Psicolingüística del español Madrid: Trota pp. 535-569.

6. Luria AR (2009) Las funciones corticales superiores en el hombre [Internet]. La Habana: Editorial Científico-Técnica.

7. Buendía J (2012) Gerontología y salud. Perspectivas actuals. Madrid: Biblioteca nueva; Disponible en: https://www.agapea.com/.../ Gerontologia-y-salud-Perspectivas-actuales-97884703041

8. Madruga F, Castellote FJ, Serrano F, Pizarro A, Luengo C, et al. (2013) Índice de Katz y escala de Barthel como indicadores de respuesta funcional en el anciano. Rev Esp Geriatr Gerontol 27(8):130.

9. Hernández P, Benítez MA, Barreto J, Rodríguez H, Torres A (2014) Despistaje en el anciano de dependencia funcional y riesgo de institucionalización. Aten Primaria 10(8): 140.

10. Valderrama E, Pérez del Molino J (2014) Una visión crítica de las escalas de valoración funcional traducidas al castellano. Rev Esp Geriatr Gerontol 32(5): 297-306.

11. Salva A, Vellar B, Albarede JC (2013) Evaluación gerontológica. Primeros resultados de una unidad de evaluación geriátrica. Rev Gerontol 4: 174179.

12. Abanto JJ, Martínez T (2013) La ayuda a domicilio en Zaragoza: Valoración cualitativa y cuantitativa. Rev Esp Geriatr Gerontol 26: 197 202.

13. Guzmán Olea E, Pimentel Pérez BM, Salas Casas A, Armenta Carrasco AI, Oliver González LB (2016) Prevención a la dependencia física y al deterioro cognitivo mediante la implementación de un programa de rehabilitación temprana en adultos mayores institucionalizados. Acta univ 26(6).

14. Marinês Tambara L, Castioni D, Kirchner RM, Hildebrandt LM (2015) Capacidad funcional y nivel cognitivo de adultos mayores residentes en una comunidad en el sur de Brasil. Enferm Glob 14(37).

15. Rodríguez Blanco L, Sotolongo Arró O, Luberta Noy G, Calvo Rodríguez M (2013) Comportamiento de la depresión en el adulto mayor del policlínico “Cristóbal Labra”. Rev Cub Med Gen Integr 29(1): 64-75.

16. Clemente F (2013) Reducción de la ansiedad, la depresión geriátrica y la preocupación en una muestra de adultos mayores a través de un programa de entrenamiento en mindfulness. Ter Psicol 35(1): 71-79.

17. Segura Cardona A, Cardona Arango D, Garzón Duque M (2015) Riesgo de depresión y factores asociados en adultos mayores. Antioquia, Colombia-2012. Rev Salud Pública 17(2): 184-194.

18. Giacoman C, Funes D, Guzmán L, Montiel T (2015) Depresión y escolaridad en adultos mayores. Diálogos educación 1(2).

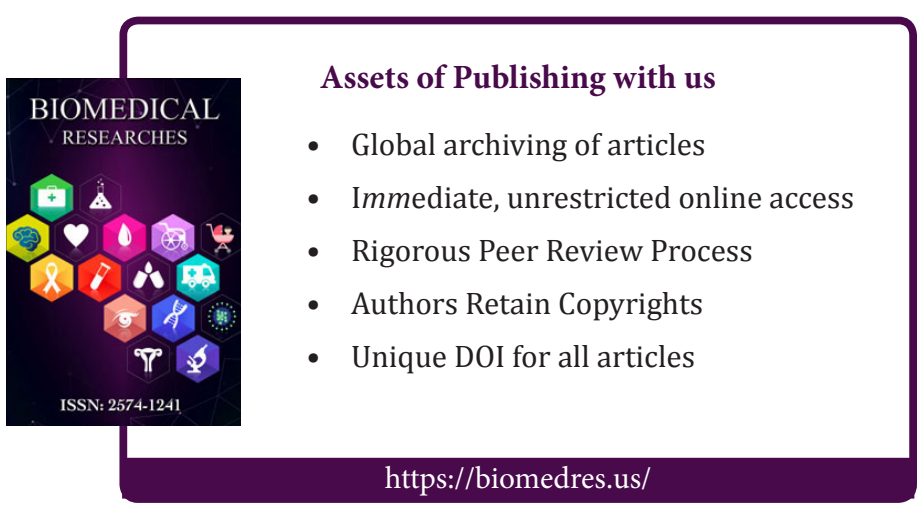

